\title{
Heavy Metal Pollution in the Birim River of Ghana
}

\author{
Bright Oppong Afum ${ }^{1}$, Clement Kwasi Owusu \\ ${ }^{1}$ Mining Engineering Department, University of Mines and Technology, Tarkwa, Ghana \\ ${ }^{2}$ Minerals Engineering Department, University of Mines and Technology, Tarkwa, Ghana
}

\section{Email address:}

boafum@umat.edu.gh (B. O. Afum)

To cite this article:

Bright Oppong Afum, Clement Kwasi Owusu. Heavy Metal Pollution in the Birim River of Ghana. International Journal of Environmental Monitoring and Analysis. Vol. 4, No. 3, 2016, pp. 65-74. doi: 10.11648/j.ijema.20160403.11

Received: February 11, 2016; Accepted: February 23, 2016; Published: April 20, 2016

\begin{abstract}
The Birim River, one of the main tributaries of the Pra River is among the important freshwater bodies in Ghana which serves as a rich source for gold and diamond production in the country. Artisanal mining activities along river bodies promote continual introduction of wide range of contaminants (heavy metals) into these water bodies, and their toxicity poses great threat to the ecology as well as the environment. This study assesses the level of heavy metals ( $\mathrm{Cr}, \mathrm{Fe}, \mathrm{Ni}, \mathrm{Zn}, \mathrm{As}, \mathrm{Cd}, \mathrm{Hg}$ and $\mathrm{Pb}$ ) in the Birim River of Ghana. The concentrations of the heavy metals were determined by Atomic Absorption Spectrophotometer (AAS) and Inductively Coupled Plasma - Mass Spectrometer (ICP-MS). Heavy metals concentration were analysed in the dissolved, suspended mineral fractions, and sediment phases of the River. The result obtained showed that the Birim River is heavily polluted with heavy metals. Samples [Apapam (KB2), Ahwenease (KB3), Adadeatem (KB4), Adukrom (KB5), Akim (KA2), Abodom (KA3), Kade (KA4), Anweaso (KA10) and Kusi (KA11)] with high heavy metals concentrations are located in areas where small scale mining is dominant, indicating that the major contamination source in the water body is resulting from small scale mining activities. Heavy metals concentration measured as dissolved were lower than WHO standards with the exception of Fe. There are high accumulations of heavy metals in the suspended mineral fractions of the river. The sediments were also greatly polluted with heavy metal sinks.
\end{abstract}

Keywords: Dissolved, Suspended Mineral Fraction, Pollution Load, Contaminants, Precipitate

\section{Introduction}

The control of water pollution in recent times has become the primary concern in developed and several developing countries in the world. In the developed world, metal pollution of water bodies is primarily caused by fossil fuel combustion, waste incineration, historic mine wastes, etc., whereas in most developing nations metal pollution is attributable chiefly to mining, particularly gold mining. The environmental impact of small-scale gold mining in developing countries and sub-Saharan Africa is well documented [1, 2, 3, 4, 5, 6]. Presently, Ghana is one of the country's in which the environmental impacts of small scale gold-mining activities are becoming increasingly unmanageable [7]. As a result, there is budding public concern about the condition of fresh waters in Ghana due to the rapid growing nature of small scale mining industry. Small scale mining in Ghana is defined as "mining by any method not involving substantial expenditure by any individual or group of persons not exceeding nine in number or by a cooperative society made up of ten or more persons" $[8,19]$.

Small scale mining, also termed artisanal gold mining (AGM) started as early as the 4th century in Ghana, and since that time, gold has been extracted from alluvial deposits in rivers, waterways, outcrops and subsurface sediments along the side of dried-up valleys through $\mathrm{Hg}$ amalgamation technique $[3,10,11]$.

Illegal artisanal mining in Ghana are unlicensed or unregulated. Their activities cause a continual introduction of wide range of contaminants into most water bodies, and the associated toxicity poses great threat to the ecology as well as the environment. Among these contaminants are heavy metals including $\mathrm{Pb}, \mathrm{Cu}, \mathrm{Cd}, \mathrm{Cr}, \mathrm{Zn}, \mathrm{Ni}, \mathrm{As}$, and $\mathrm{Hg}$ [12]. These heavy metals can have adverse effect on human metabolism and health. For example, bioaccumulation of heavy metals can damage the central nervous system, lungs, kidneys, liver, endocrine glands, and bones. 
In Ghana, most communities are found along rivers. These communities in Ghana are usually named after such rivers (e.g. Huniso, Densuso, Subriso, Praso, Bonsaso, Bogoso, etc.). These rivers are highly dependent by local inhabitants for domestic and economic activities including fishing and sources of water for agri-businesses.

Previous studies [14] have shown that mining is the main pollution source in the Birim River. The prevailing condition of the river is of serious concern, and there is an urgent need to take strict measures to ensure cleansing of the river and prevent further contamination despite the existing numerous localisations of small scale mining activities in the basin. According to [14], the Birim basin has not been extensively studied as an entity. To date, there is little or no detailed information on the concentrations, mobility and the general pollution loads in the Birim River.

This paper reports on the concentrations, mobility, and the general pollution loads of heavy metals in the Birim River of Ghana.

\section{Materials and Methods}

\subsection{Study Area}

The Birim River is one of the most important freshwater bodies in Ghana. It flows from the Atewa range of hills in the Eastern Region and joins the River Pra, which is another major freshwater body in Ghana. It follows a course of about
$181 \mathrm{~km}$ before joining the Pra River. The Birim river flows through major communities including Akim Apapam, Anyinam, Oda, Kibi, Kade, Akwatia, Abomoso, Akim Abodom, Osino, with a total district population of about 2.6 million [13]. However, it is one of the river basins intensively localised with many small scale mining operations (predominantly gold and diamond). The main methods of mining operations identified in the Birim basin are open pits, direct dredging and panning. Apart from mining, the main socio-economic activities along the river are farming, palm kennel and palm oil production.

The geology of the study area is associated with the Birimian foundation and the Voltaian metamorphosed sediments with associated rocks such as phylites, schist and granites. Studies conducted by [15] revealed that the Birimian volcanic rocks, Birimian sedimentary rocks and the Cape Coast-type granitoid that made-up the study area consist of dominantly tholeitic mafic lavas, with lesser amounts of andesite lavas and felsic volcanics whereas the sedimentary components are manganiferous phyllites, cherts, carbonates and quartz arenites. The valleys, over which the river flows, are underlain by thick sequences of metasediments - greywacke, argillite, and phyllite [16]. Due to the existing unregulated or illegal artisanal mining activities, the river is generally muddy with the river bed consisting of precipitated mud, sand, gravels and rocks. Fig. 1 shows the study area along the Birim River per this report.

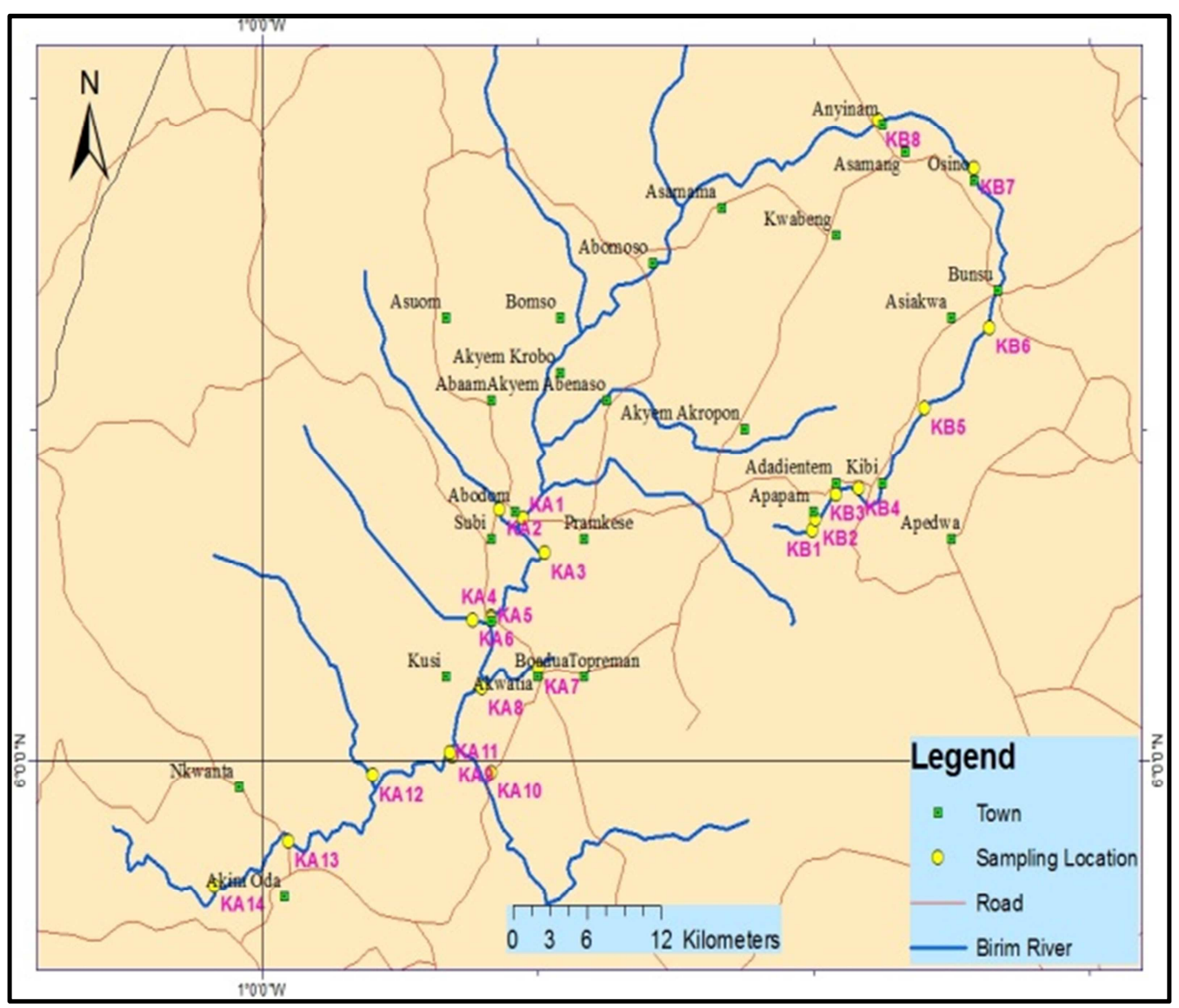

Fig. 1. Sampling locations along the Birim river of the study area. 


\subsection{Sampling Locations}

Twenty two (22) samples (which include tributaries) were taken along the course of the Birim River from two sections or sites of the river (A and B). Site A describes samples obtained from the lower sections of the river, thus, from Akyem Abodom to Gyadem near Akim Oda through major towns such as Kade, Akwatia and Kusi; whilst Site B represent samples obtained from the upper sections of the river, thus, from the source of the Birim River to Anyinam (a major town on the main road from Accra to Kumasi) through major towns including Osino and Adukrom. Fig. 1 shows the sampling locations along the Birim River. KA and $\mathrm{KB}$ represent, respectively, samples taken from study site $\mathrm{A}$ and $\mathrm{B}$.

Sampling protocols and sampling site selection followed that described by [17]. The sampling sites were also selected based on accessibility and the proximity of the sites to the various towns along the course of the river. Water and sediment samples were obtained at each sampling location along the river. Garmin Geographical Positioning Systems (GPS) for taking spatial geo-positions of sampling points was employed for this study. Generally, the nature of the Birim water in both study areas (A and B) was very turbid, milkybrown in colour, and shows indications of highly suspended sediments. However, the tributaries were relatively clearer and brighter compared to the main course of the river.

\subsection{Sampling and Preservation}

For all the sampling points, the water samples were collected in the direction opposite to the flow of the river. This was done to prevent/minimise the direct release of other contaminants from the human body that might affect the sampling accuracy. At each sampling site, the water was filtered through $0.45 \mu \mathrm{m}$ micro-glass fibre filter membrane with a hand held pump and Nalgene polysulphone filter unit. An approximate quantity of $250 \mathrm{ml}$ water was filtered into 60 $\mathrm{ml}$ and $125 \mathrm{ml}$ black polyethylene containers.

The filter papers used for the filtration were carefully folded into air-tight plastic whirl-pak bags with the aid of tweezers. As much as possible, air bubbles were secluded in each sampling bottle. Three (3) drops of $50 \%$ concentrated ultrapure $\mathrm{HNO}_{3}$ acid were added to the $125 \mathrm{ml}$ water samples which were intended for cation (metal) analysis whilst the 60 $\mathrm{ml}$ water sampled bottles intended for anion analysis were not acidified. These samples were later kept in temperature controlled and monitored iced-chest at $4{ }^{\circ} \mathrm{C}$ on the field but later stored in a refrigeration system after the field work and the temperature set and monitored at $4^{\circ} \mathrm{C}$ before transportation to the laboratory for analyses. Preservation of the samples was done according to [18].

The sediment samples were obtained as much as possible from the exact vertical position of the water sampling points. However, for sampling locations of difficult accessibility, sediment samples were obtained close to where the water samples were collected. The sampled river sediments were air dried under a less windy shady environment and carefully repacked into paper bags for transportation to the laboratory for analyses.

All the collected samples were packed into insulated thermal bags and transported to the laboratory of the Environmental Department of the Institute of Geography and Earth Sciences (IGES) of Aberystwyth University, United Kingdom. Upon arrival at the laboratory, the sediment samples were quickly oven dried at $65^{\circ} \mathrm{C}$ for approximately $72 \mathrm{hrs}$ before cooling to normal room temperature whilst the water and filter cake samples stored in the refrigerator at $4{ }^{\circ} \mathrm{C}$.

\subsection{Analytical Technique}

Samples were analysed for metal concentrations of $\mathrm{Cr}$, $\mathrm{Fe}$, $\mathrm{Ni}, \mathrm{Zn}, \mathrm{As}, \mathrm{Cd}, \mathrm{Hg}$ and $\mathrm{Pb}$ using the Perkin-Elmer $\mathrm{AA}$ analyst 400 Atomic Absorption Spectrophotometer (AAS), and the Agilent 7700 Inductively Coupled Plasma - Mass Spectrometer (ICP-MS).

\subsubsection{Atomic Absorption Spectrometer (AAS)}

The AAS is a spectroanalytical procedure for the quantitative determination of chemical elements employing the absorption of optical radiation (light) by free atoms in the gaseous state. It is a well-established technique for metal determination, being the instrumental method of choice for aqueous samples in geochemical laboratories for 20 years between the mid-1960s and mid 1980s [19].

The technique makes use of absorption spectrometry to assess the concentration of an analyte in a sample. It is based on the phenomenon that the atom in the ground state absorbs the light of wavelengths that are characteristic to each element when light is passed through the atoms in the vapour state. Because this absorption of light depends on the concentration of atoms in the vapour, the concentration of the target element in the water sample is determined from the measured absorbance.

\subsubsection{Inductive Coupled Plasma - Mass Spectrometer (ICP-MS)}

The Agilent 7700 ICP-MS was used in analysing the major and trace elements content of the samples. The details and mode of operation has been reported [20]. Generally, the concentrations of the elements in the sample are calculated by taking the peak area for a single isotope of the element of interest. According to [21], the precision of the ICP-MS is between 2 and 5\% relative standard deviation (RSD) while accuracy is better than $5 \%$ absolute. It also provides near determination of most elements in the periodic table at levels down to $10 \mathrm{pg} / \mathrm{ml}$.

\section{Results and Discussions}

\subsection{Heavy Metal Concentrations of the River}

The concentrations of the heavy metals in all the samples and its considered tributaries were measured as dissolved 
pollutants (thus, elements passing through the $0.45 \mu \mathrm{m}$ filter paper), suspended sediments (elements in the cake on the filter paper after filtration), and easily available or labile pollutants (elements present in suspended materials settled to the river bed).

\subsubsection{Dissolved Metal Concentration}

Table 1 shows the measured dissolved concentrations of heavy metals $(\mathrm{Cr}, \mathrm{Fe}, \mathrm{Ni}, \mathrm{Zn}, \mathrm{As}, \mathrm{Cd}, \mathrm{Hg}$ and $\mathrm{Pb}$ ) in water samples taken from the 22 sites along the Birim River and the WHO standards for the various metals in fresh natural waters. Comparatively, the measured dissolved concentrations of heavy metals from all the sampling sites were below the WHO standards except for Fe. All the measured dissolved Fe concentrations along the Birim River for Study Area A were all above the World Health Organisation (WHO) standard of $0.30 \mathrm{mgL}^{-1}$.

Fig. 2 is a contamination map of the study areas showing $\mathrm{Fe}$ concentrations along the Birim River. Expectedly, the Fe concentrations at the near source of the river (KB1) was Nil, indicating that mining activities through exposure of rocks to weathering and leaching contributes massively to heavy metal pollutions in the Birim River. The variations in the levels of heavy metals concentrations from site A and B, may explain the degree of pollution in the two sites. It also shows that, mining activities disseminated along Site A, are more intense compared to Site B. For example, high $\mathrm{Fe}$ concentrations recorded for Site A compared to Site B suggest that, Site A, is more polluted in Fe than Site B. The high $\mathrm{Fe}$ concentration observed for study area A and KB 6 can be related to the ferrigineous nature of the river sediments resulting from the weathering of the Birim rock system as a result of illegal mining in the river basin.

The Birimian rock system making up of granites contains high amounts of iron and other toxic chemicals such as manganese. Rock analysis conducted by [22] showed that $\mathrm{Fe}_{2} \mathrm{O}_{3}$ composition in granite is approximately $2.8 \%$, serving primarily as the major source for Fe in fresh waters. Other sources for the high Fe concentration observed may be related to the continual discharging of mining waste generated from small scale mining activities.

Iron is an essential element in the human nutrition. However, the toxicity of iron to the human body is governed by the absorption rate. Thus, the more one takes in Fe, the more one is at risk. The estimates of the minimum daily requirement for iron depend on age, sex, physiological status, and iron bioavailability, and ranges from about 10 to 50 $\mathrm{mg} /$ day [23]. The ingestion of high amounts of Fe in drinking water can pose health problems such as anorexia, oligura, diarrhoea, hypothermia, metabolic acidosis and in some cases death. Hepatoma, the primary cancer of the liver has become the most common death among patients with hemochromatosis [24].

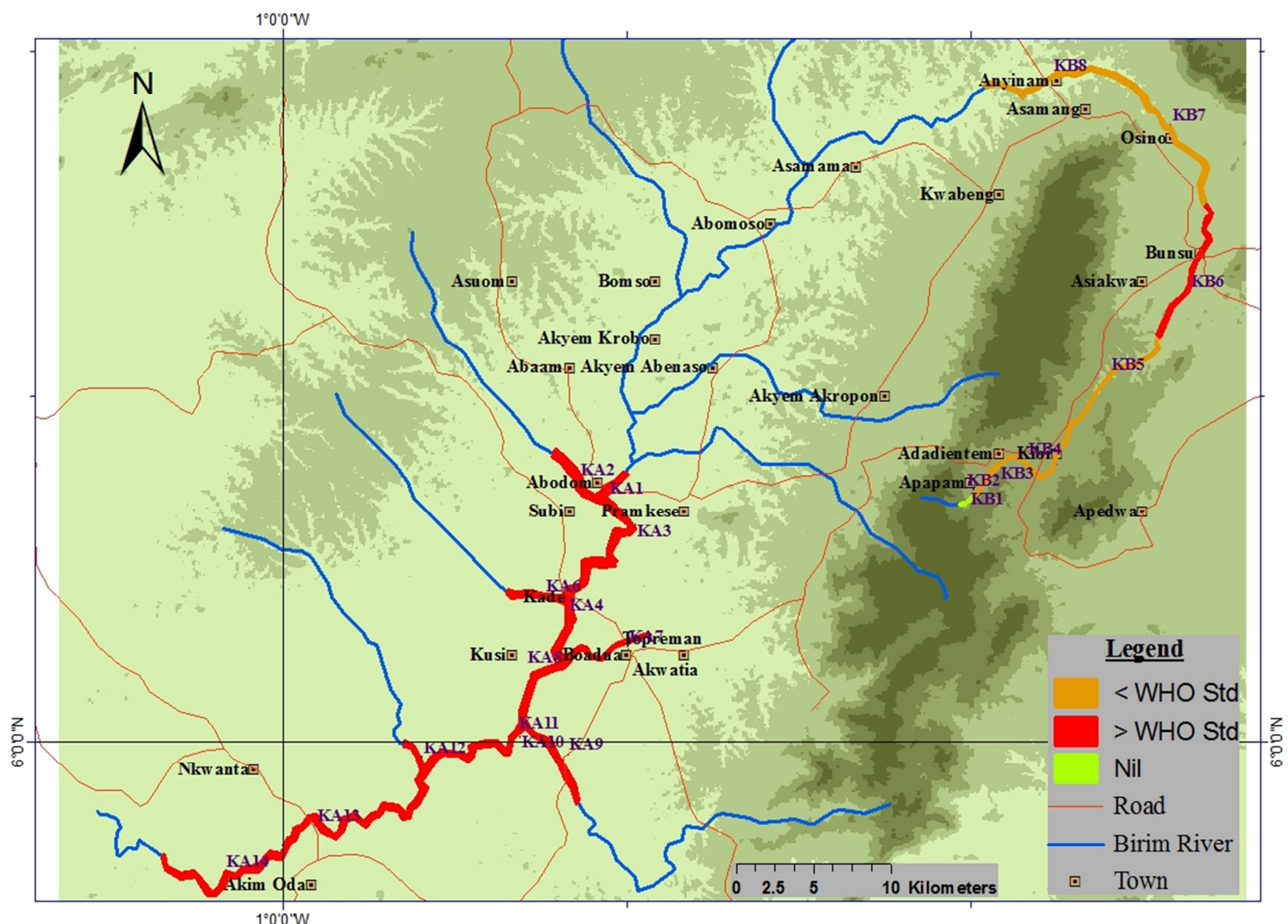

Fig. 2. Dissolved Fe concentrations along the Birim River per study area. 
Table 1. Metal concentrations in water samples - Dissolved (mg/L).

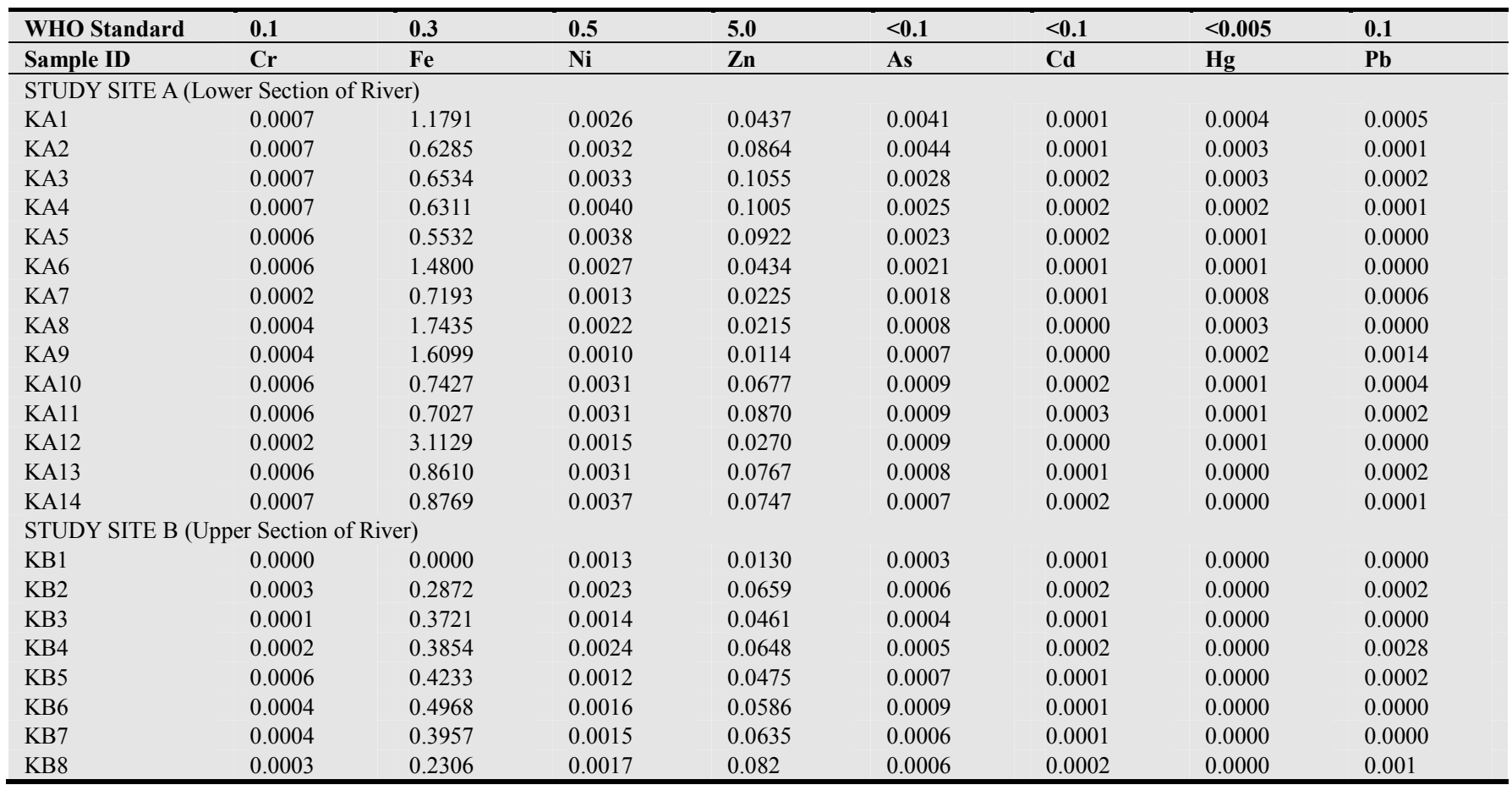

Table 2. The concentration of metals in the suspended particulates $(\mathrm{mg} / \mathrm{L})$.

\begin{tabular}{|c|c|c|c|c|c|c|c|c|c|}
\hline Sample ID & Distance (km) & $\mathbf{C r}$ & $\mathbf{F e}$ & $\mathbf{N i}$ & $\mathbf{Z n}$ & As & $\mathbf{C d}$ & Hg & $\mathbf{P b}$ \\
\hline \multicolumn{10}{|c|}{ STUDY SITE A (Lower Section of River) } \\
\hline KA1 & 0.00 & 0.00 & 2041.95 & 0.00 & 0.00 & 0.00 & 0.00 & 1748.00 & 2.44 \\
\hline KA2 & 0.82 & 115.21 & 34181.98 & 35.29 & 0.00 & 9.42 & 0.00 & 0 & 0.00 \\
\hline KA3 & 3.46 & 0.00 & 0.00 & 0.00 & 0.00 & 0.00 & 0.00 & 0 & 0.00 \\
\hline KA4 & 11.31 & 0.00 & 0.00 & 0.00 & 0.00 & 0.00 & 0.00 & 0 & 0.00 \\
\hline KA5 & 11.68 & 21.93 & 104401.04 & 55.08 & 0.00 & 0.00 & 0.00 & 0 & 0.00 \\
\hline KA6 & 12.07 & 0.00 & 0.00 & 0.00 & 0.00 & 0.00 & 0.00 & 0.06 & 10.65 \\
\hline KA7 & 16.41 & 26.00 & 17018.73 & 11.85 & 1487.95 & 0.00 & 1.15 & 0.06 & 44.12 \\
\hline KA8 & 17.14 & 47.19 & 32292.56 & 19.36 & 2611.01 & 0.00 & 0.00 & 0.09 & 17.52 \\
\hline KA9 & 21.95 & 0.00 & 0.00 & 0.00 & 0.00 & 0.00 & 0.00 & 0.04 & 0.00 \\
\hline KA10 & 27.54 & 173.70 & 54488.36 & 62.67 & 0.00 & 3.86 & 7.45 & 0 & 0.00 \\
\hline KA11 & 27.85 & 225.51 & 72746.96 & 82.64 & 14499.80 & 12.70 & 1.79 & 0 & 51.05 \\
\hline KA12 & 36.13 & 0.00 & 0.00 & 0.00 & 0.00 & 0.00 & 0.00 & 0.04 & 12.86 \\
\hline KA13 & 47.03 & 0.00 & 0.00 & 0.00 & 0.00 & 0.00 & 0.00 & 0 & 0.00 \\
\hline KA14 & 55.32 & 0.00 & 0.00 & 0.00 & 0.00 & 0.00 & 0.00 & 0 & 0.00 \\
\hline \multicolumn{10}{|c|}{ STUDY SITE B (Upper Section of River) } \\
\hline KB1 & 0.00 & 0.00 & 0.00 & 0.00 & 0.00 & 0.00 & 0.00 & 0.06 & 10.33 \\
\hline KB2 & 0.83 & 140.64 & 94359.30 & 60.49 & 0.00 & 6.61 & 0.00 & 25620.00 & 0.00 \\
\hline KB3 & 3.09 & 150.46 & 80826.50 & 60.83 & 8525.64 & 10.13 & 4.64 & 0.15 & 53.03 \\
\hline KB4 & 5.10 & 176.67 & 85203.10 & 71.45 & 0.00 & 9.15 & 0.00 & 0.38 & 0.00 \\
\hline KB5 & 14.13 & 97.48 & 30064.00 & 38.80 & 0.00 & 5.75 & 0.00 & 0.25 & 0.00 \\
\hline KB6 & 22.21 & 0.00 & 0.00 & 0.00 & 0.00 & 0.00 & 0.00 & 0.19 & 0.00 \\
\hline KB7 & 34.57 & 0.00 & 0.00 & 0.00 & 0.00 & 0.00 & 0.00 & 0.42 & 0.00 \\
\hline KB8 & 43.62 & 0.00 & 0.00 & 0.00 & 0.00 & 0.00 & 0.00 & 0.42 & 0.00 \\
\hline
\end{tabular}

\subsubsection{Suspended Particulates Concentration}

Table 2 shows the metals concentration in the suspended mineral fraction of the Birim River. Generally, the metals concentrations varied significantly at both studied sites A and $\mathrm{B}$ of the river. Site $\mathrm{B}$ recorded the highest metal concentrations for Fe (KA5: 10,4401.04 mg/L), $\mathrm{Hg}(\mathrm{KB} 2$ : 25,620.00 mg/L) and $\mathrm{Pb}(\mathrm{KB} 3: 53.03 \mathrm{mg} / \mathrm{L})$ whilst the highest metal concentrations for $\mathrm{Cr}$ (KA11: $225.51 \mathrm{mg} / \mathrm{L}), \mathrm{Ni}$ (KA11: $82.64 \mathrm{mg} / \mathrm{L}), \mathrm{Zn}$ (KA11: 14,499.80 mg/L), As (KA11: $12.70 \mathrm{mg} / \mathrm{L}$ ) and $\mathrm{Cd}(\mathrm{KA} 10: 7.45 \mathrm{mg} / \mathrm{L})$ were recorded at Site A. The concentration of heavy metals measured as dissolved is significantly low compared to those measured in the suspended fraction, suggesting higher accumulation of heavy metals in the suspended particulate fractions of the river.

Furthermore, all the measured $\mathrm{Hg}$ concentration levels for Site A were relatively low compared to those recorded for Site B. The highest Hg concentration level (KB2: 25,620.00 $\mathrm{mg} / \mathrm{L}$ ) was measured about $830 \mathrm{~m}$ downstream the referenced source of the Birim river. Dredging of the river 
sediments for gold was being undertaken during sampling at this point (KB2). This indicates the direct discharge of $\mathrm{Hg}$ used for gold amalgamation into the river. Sample point KA11 recorded the highest $\mathrm{Cr}(225.51 \mathrm{mg} / \mathrm{L}), \mathrm{Ni}(82.64$ $\mathrm{mg} / \mathrm{L}), \quad \mathrm{Zn} \quad(14,499.80 \mathrm{mg} / \mathrm{L})$ and As $(12.70 \mathrm{mg} / \mathrm{L})$ concentration levels whilst KB3 recorded the highest metal concentration for $\mathrm{Pb}(53.03 \mathrm{mg} / \mathrm{L})$. Sampling sites KA11 and KB2 also recorded highest measured levels of $\mathrm{Cd}(7.45$ $\mathrm{mg} / \mathrm{L})$ and $\mathrm{Hg}(25,620.00 \mathrm{mg} / \mathrm{L})$ respectively.

It is noteworthy from Tables 1 and 2 that, one of the things that can be done by the communities that depend on the river for domestic and drinking purposes to minimise the contamination level of heavy metals without any major treatment is by filtration, although, that for $\mathrm{Fe}$ still remains higher when compared to the WHO standard.

Sample points KA11, KB2 and KB3 are well-known areas with historical illegal artisanal or small scale mining for diamond and gold. Therefore, the high metal concentrations for $\mathrm{Hg}, \mathrm{Cr}, \mathrm{Ni}, \mathrm{Zn}$ and $\mathrm{As}$, observed in those areas can be attributed to anthropogenic activities resulting from the presence of illegal miners dredging the river sediments or mining in the river basin for gold and/or diamonds. Excavations made by these miners cause the contaminants to be leached out as the water washes over the rock, mud and sand surfaces in the river, and transported downstream. Cadmium recorded in some of the study areas may be related to sources including mining activities, leachate from $\mathrm{Ni}-\mathrm{Cd}$ based batteries and runoffs from agricultural fields where phosphate fertilizer might be in use [25].

\subsubsection{Sediment (Labile) Metal Concentration}

Generally, suspended sediment adsorbed pollutants from flowing water in rivers and deposits onto the bed. The accumulation of pollutants in the river bed sediment however, can affect the bio-community through food chain for a long period of time. As a result, assessment of the river sediments through weak digestion for all the sediment samples were conducted to have an idea on the labile fraction of metal contaminants available in river sediments that could easily be released into the aquatic environment. The results are presented in Table 3.

The high level of metal concentration in the river sediment relative to levels in the water as dissolved and suspended is expected since sediments have been described as a sink or reservoir for pollutants in water [26]. Again, for the sediment samples, Fe recorded highest metal concentration at all sampled points, which reaffirm the hypothesis that the river is heavily polluted in Fe. Moreover, the metal concentration levels for the other heavy metals $(\mathrm{Hg}, \mathrm{Pb}, \mathrm{As}, \mathrm{Zn}, \mathrm{Ni}, \mathrm{Fe}$, and $\mathrm{Cr}$ ) for both sites A and B were relatively high. Interestingly, $\mathrm{Cd}$ was not found in the sediment samples. This may be as a result of the digestion method used and/or the absence of precipitates or complexes of $\mathrm{Cd}$ in the sediments of the river.

These results suggest that consumption of the polluted water by animals or human beings could be hazardous to their health. For example, once mercury is in the water, it is easily adsorbed to the suspended particulates including micro-organisms which enters into the food chain through the consumption by fishes or sinks into the river sediment before being transported downstream. The larger sediment sinks to the bottom but later re-enters the aquatic system when floodplain materials are reworked by erosion [27]. Similarly, accumulation of As in river sediment with time can dissolve back into the river, which when ingested can cause multiple internal cancers in the liver, kidney, lung and bladder [28].

Table 3. The concentration of metals in the river sediment (liable, $\mathrm{mg} / \mathrm{kg}$ ).

\begin{tabular}{|c|c|c|c|c|c|c|c|c|c|}
\hline Sample ID & Distance (km) & $\mathbf{C r}$ & $\mathbf{F e}$ & $\mathrm{Ni}$ & $\mathbf{Z n}$ & As & Cd & Hg & $\mathbf{P b}$ \\
\hline \multicolumn{10}{|c|}{ STUDY SITE A (Lower Section of River) } \\
\hline KA1 & 0.00 & 1.34 & 1677.61 & 0.91 & 2.78 & 0.58 & - & 0.01 & 5.04 \\
\hline KA2 & 0.82 & 1.82 & 2725.24 & 1.91 & 3.06 & 0.61 & - & 0.12 & 3.45 \\
\hline KA3 & 3.46 & 2.23 & 3675.07 & 1.69 & 2.98 & 0.23 & - & 0.01 & 3.06 \\
\hline KA4 & 11.31 & 2.63 & 4205.54 & 1.94 & 3.71 & 0.46 & - & 0.03 & 3.89 \\
\hline KA5 & 11.68 & 1.31 & 1514.64 & 2.63 & 2.14 & 0.39 & - & 0.03 & 5.82 \\
\hline KA6 & 12.07 & 1.63 & 1306.65 & 0.42 & 1.7 & 0.71 & - & 0.02 & 5.7 \\
\hline KA7 & 16.41 & 2.6 & 5073.05 & 2.31 & 9.82 & 5.67 & - & 0.03 & 6.79 \\
\hline KA8 & 17.14 & 1.58 & 2135.84 & 1.30 & 2.11 & 0.08 & - & 0.02 & 2.81 \\
\hline KA9 & 21.95 & 4.69 & 1504.4 & 6.28 & 2.1 & 0.09 & - & 0.42 & 2.06 \\
\hline KA10 & 27.54 & 4.35 & 1121.91 & 7.91 & 1.74 & 0.00 & - & 0.02 & 2.68 \\
\hline KA11 & 27.85 & 1.26 & 1064.29 & 1.03 & 1.51 & NA & - & 0.01 & 2.61 \\
\hline KA12 & 36.13 & 1.48 & 1906.6 & 0.64 & 4.5 & 0.57 & - & 0.15 & 5.13 \\
\hline KA13 & 47.03 & 1.78 & 2846.01 & 1.92 & 3.19 & 0.39 & - & 0.04 & 9.36 \\
\hline KA14 & 55.32 & 1.2 & 1908.43 & 1.7 & 5.35 & 1.18 & - & 0.09 & 4.15 \\
\hline \multicolumn{10}{|c|}{ STUDY SITE B (Upper Section of River) } \\
\hline KB1 & 0.00 & 4.93 & 5516.97 & 3.85 & 6.12 & NA & - & 0.04 & 5.55 \\
\hline KB2 & 0.83 & 2.07 & 6108.58 & 3.43 & 17.87 & 0.14 & - & 0.09 & 6.1 \\
\hline KB3 & 3.09 & 2.12 & 4399.65 & 2.64 & 6.68 & 0.71 & - & 0.06 & 4.57 \\
\hline KB4 & 5.1 & 2.49 & 4883.72 & 4.22 & 5.58 & 0.97 & - & 0.2 & 4.23 \\
\hline KB5 & 14.13 & 2.51 & 4438.22 & 2.91 & 4.01 & 0.83 & - & 0.05 & 4.02 \\
\hline KB6 & 22.21 & 3.12 & 4868.65 & 4.41 & 5.7 & 1.55 & - & 0.04 & 5.86 \\
\hline KB7 & 34.57 & 5.4 & 13554.2 & 5.82 & 10.86 & 6.7 & - & 0.03 & 6.61 \\
\hline KB8 & 43.62 & 5.06 & 10702.4 & 4.36 & 9.41 & 5.31 & - & 0.04 & 8.53 \\
\hline
\end{tabular}




\subsection{Extent of Pollution of the Birim River}

The extent of pollution of natural water systems aids in defining the sources of pollution, remediation technique adopted, and areas or locations along the course of the stream or river that needs remediation attention. The extent of pollution for heavy metal load can be estimated by determining the background concentrations of species in the river body and subtracting it from the total measured species concentration at various sampling points along the river course. It also provides idea on the total enrichment caused by natural geochemical processes and other anthropogenic activities. According to [29, 30, 31], the preferred approach for estimating the background concentrations of a river is to collect samples from the stream or geological formation of interest somewhere near the source, where the water quality has presumably not been altered or disturbed by human activity.

In this study, the background of the Birim River was determined by sampling at a location nearer to the source of the river (referenced river source, KB1 - Outskirt of Apapam towards Atewa Range), where the waters rush out of the creeks of the Atewa range of hills with no anthropogenic activity at its upstream waters. The estimations of the pollution load per this study were based on the suspended mineral fractions of the river and precipitated or labile pollutants present in the Birim River.

\subsubsection{Pollution Load (Suspended Particulates)}

The estimated pollution load per suspended mineral fractions in the Birim River is summarised in Table 4 for all the various sampling locations along the main river of the study area. From Table 4, it is very clear that sampling locations with massive mining activities - Apapam (KB2), Ahwenease (KB3), Adadeatem (KB4), Adukrom (KB5), Akim Abodom (KA1), Kade (KA4), and Anweaso (KA11) had accumulated relatively high concentrations of metals including $\mathrm{Fe}, \mathrm{Ni}, \mathrm{As}, \mathrm{Zn}, \mathrm{Hg}$, and $\mathrm{Cr}$; with $\mathrm{KB} 2$ recording high $\mathrm{Hg}$ concentration of $25,619.9 \mathrm{mgL}^{-1}$.

The anthropogenic release of pollutants from these mining activities and the inter-relationship between the released metals, geology and geological processes of the area have greatly and negatively affected the quality of the Birim river by introducing much pollutants into the suspension of the river. The accumulation of relatively high concentrations of metals ( $\mathrm{Fe}, \mathrm{Ni}, \mathrm{As}, \mathrm{Hg}, \mathrm{Zn}$, and $\mathrm{Cr}$ ) can be related to the mixing of the sediments through anthropogenic dredging, panning and pitting activities in and around the Birim River basin during mining activities for gold and/or diamonds. These encourage geochemical processes (including weathering or leaching of rocks surfaces) and other processes such as ion-exchange, adsorption and desorption, dissociation, precipitation, etc.

\subsubsection{Pollution Load (Labile or Precipitated)}

Geochemical processes including redox reactions, adsorption, sorption, precipitation, ion-exchange, and methylation of free and organo-metallic metals in rivers cause the deposition of heavy metals to the bottom of such rivers. The main sink of the heavy metals present in the particulate matter of the river increases the pollution load accumulation in the river sediments. Table 5 shows the estimated labile mineral fractions pollution load accumulation in the sediments of the Birim River along its course.

The load in the river sediments are easily available to the aquatic system, and hence affect the river quality through major physical, geological and geochemical processes occurring in the river. These processes which include hydrolysis, solubilisation, dissolution, methylation, ionexchange, complexation etc. enable metal ions to be released from the sediments into the river through prevailing conditions.

Table 4. Pollution load estimates of suspended mineral fractions along the river $\left(m g L^{-1}\right)$.

\begin{tabular}{|c|c|c|c|c|c|c|c|c|c|}
\hline Sample ID & Distance (km) & $\mathbf{C r}$ & $\mathrm{Fe}$ & $\mathrm{Ni}$ & $\mathbf{Z n}$ & As & Cd & $\mathrm{Hg}$ & $\mathbf{P b}$ \\
\hline *KB1 & $\mathbf{0}$ & $\mathbf{0}$ & $\mathbf{0}$ & $\mathbf{0}$ & $\mathbf{0}$ & $\mathbf{0}$ & $\mathbf{0}$ & 0.06 & 10.33 \\
\hline KB2 & 0.83 & 140.64 & 94359.3 & 60.49 & 0 & 6.61 & 0 & 25619.9 & - \\
\hline KB4 & 5.1 & 176.67 & 85203.1 & 71.45 & 0 & 9.15 & 0 & 0.32 & - \\
\hline KB5 & 14.13 & 97.48 & 30064 & 38.8 & 0 & 5.75 & 0 & 0.18 & - \\
\hline KB6 & 22.21 & 0 & 0 & 0 & 0 & 0 & 0 & 0.13 & - \\
\hline KB7 & 34.57 & 0 & 0 & 0 & 0 & 0 & 0 & 0.36 & - \\
\hline KB8 & 43.62 & 0 & 0 & 0 & 0 & 0 & 0 & 0.36 & - \\
\hline KA1 & 0 & 115.21 & 34182 & 35.29 & 0 & 9.42 & 0 & - & - \\
\hline KA3 & 3.46 & 0 & 0 & 0 & 0 & 0 & 0 & - & - \\
\hline KA4 & 11.31 & 21.93 & 104401 & 55.08 & 0 & 0 & 0 & - & - \\
\hline KA5 & 11.68 & 0 & 0 & 0 & 0 & 0 & 0 & - & - \\
\hline KA11 & 27.85 & 47.19 & 32292.6 & 19.36 & 2611.01 & 0 & 1.79 & - & - \\
\hline KA14 & 55.32 & 0 & 0 & 0 & 0 & 0 & 0 & - & - \\
\hline
\end{tabular}

*KB1 represents the background concentrations of suspended mineral fractions in the River 
Table 5. Pollution load estimates of labile elements of the Birim River (mg/kg).

\begin{tabular}{|c|c|c|c|c|c|c|c|}
\hline Sample ID & Distance (km) & $\mathrm{Cr}$ & $\mathbf{F e}$ & $\mathbf{N i}$ & $\mathbf{Z n}$ & $\mathbf{H g}$ & $\mathbf{P b}$ \\
\hline *KB1 & 0.00 & 4.93 & 5516.97 & 3.85 & 6.12 & 0.04 & 5.55 \\
\hline KB2 & 0.83 & - & 591.60 & - & 11.76 & 0.05 & 0.55 \\
\hline KB3 & 3.09 & - & - & - & 0.56 & 0.02 & - \\
\hline KB4 & 5.10 & - & - & 0.38 & - & 0.16 & - \\
\hline KB5 & 14.13 & - & - & - & - & 0.01 & - \\
\hline KB6 & 22.21 & - & - & 0.56 & - & - & 0.31 \\
\hline KB7 & 34.57 & 0.48 & 8037.26 & 1.97 & 4.74 & - & 1.06 \\
\hline KB8 & 43.62 & 0.14 & 5185.44 & 0.51 & 3.30 & 0 & 2.98 \\
\hline KA1 & 0.00 & - & - & - & - & - & - \\
\hline KA3 & 3.46 & - & - & - & - & - & - \\
\hline KA4 & 11.31 & - & - & - & - & - & - \\
\hline KA5 & 11.68 & - & - & - & - & - & 0.27 \\
\hline KA11 & 27.85 & - & - & - & - & - & - \\
\hline KA13 & 47.03 & - & - & - & - & - & 3.81 \\
\hline KA14 & 55.32 & - & - & - & - & 0.05 & - \\
\hline
\end{tabular}

\section{Conclusion}

The study ascertained the concentrations, mobility, and general pollution loads of heavy metals in the Birim River. The dissolved metal concentrations of the upper and lower sections of the Birim River are relatively lower than the critical level permitted by WHO standard for natural waters with the exception of $\mathrm{Fe}$ which showed relatively higher concentrations along the lower section. Moreover, the dissolved Fe concentrations along the upper sections of the river were relatively lower compare to Fe concentrations in the upper sections of the river. However, filtration of the water before usage for domestic and drinking purposes is highly recommended to eliminate these dissolved metals.

Metal concentrations in the suspended mineral fractions at the source of the Birim River were either absent or low with the exception of $\mathrm{Pb}$ and traces of $\mathrm{Hg}$. The exceptional metals measured at the source could be attributed to the geological erosions or organic loading in the suspended particulate matter in the river. The concentrations of metals deposited on the river bed (labile or bottom deposited ions or sediment associates), and suspended mineral fractions were very high along both the upper and lower sections of the Birim river.

The pollution load in terms of the relative accumulated concentrations of suspended mineral fractions and labile elements quantified along the considered sections of the Birim River were very high compared with its background concentrations at the source. The Birim River per the study areas has been extensively polluted at locations and towns with active mining activities - Apapam, Ahwenease, Adadeatem, Adukrom, Akim Abodom, Kade, Anweaso and Kusi. These sections of the river in the towns have accumulated relatively high concentrations of metals such as $\mathrm{Fe}, \mathrm{Mn}, \mathrm{Ni}, \mathrm{As}, \mathrm{Hg}, \mathrm{Zn}$, and $\mathrm{Cr}$. It has been identified that, the major sources of pollutants to the river results from illegal artisanal or small scale mining activities in and along the river basin.
The release of $\mathrm{Hg}$ from the small scale mining activities into the environment was outrageously high. All the measured $\mathrm{Hg}$ were found at places with active mining activities, mostly existing in the suspended phases and the precipitates at the bottom of the river. Due to the organocomplex nature of inorganic mercury, the measured $\mathrm{Hg}$ in the river body would heavily impact its aquatic system (microbes, zooplanktons, fishes, etc.) and hence humans through bioaccumulation of such metals when they enter into the food chain. As the Birim river is known to frequently flood its banks into neighbouring farms and communities during the high peak periods of the wet season, plants and humans will be extensively affected by these high metals including $\mathrm{Hg}$ in the river when it breaks its banks from heavy downpour of rain. The environment is therefore prone to heavy metal and $\mathrm{Hg}$ pollution in the resulting from activities in and around the Birim river.

\section{Acknowledgement}

The Authors wish to acknowledge the funding support of the Commonwealth Scholarship Commission and the Institute of Geography and Earth Science of the Aberystwyth University during the collection of data on the field and laboratory analyses of the samples. The support of Dr Andrew Mitchell, Dr Bill Perkins, and the Laboratory Technician - Andy, all staff of Aberystwyth University, Wales, UK and the supports of Comfort Anokyewaa Nimako, Anthony Akowuah, Hughes Affum, and Kwaku Moses who assisted in the data collection are highly acknowledged.

\section{References}

[1] Davidson, J., 1993. The transformation and successful development of small - scale mining enterprises in developing countries, Natural Resources Forum. Wiley Online Library, pp. 315-326. 
[2] Fisher, E., 2007. Occupying the margins: labour integration and social exclusion in artisanal mining in Tanzania. Development and change, 38(4): 735-760.

[3] Hilson, G., 2002. The environmental impact of small - scale gold mining in Ghana: identifying problems and possible solutions. The Geographical Journal, 168(1): 57-72.

[4] Kitula, A., 2006. The environmental and socio-economic impacts of mining on local livelihoods in Tanzania: A case study of Geita District. Journal of cleaner production, 14(3): 405-414.

[5] Meech, J. A., Veiga, M. M. and Tromans, D., 1998. Reactivity of mercury from gold mining activities in darkwater ecosystems. Ambio: 92-98.

[6] Mireku-Gyimah, D. and Suglo, R., 1993. The state of gold mining in Ghana. Transactions of the Institution of Mining and Metallurgy. Section A. Mining Industry, 102.

[7] Karikari, A., Bernasko, J. and Bosque-Hamilton, E., 2007. An assessment of water quality of Angaw River in southeastern coastal plains of Ghana. West African Journal of Applied Ecology, 11(1).

[8] Marker, B. R., Petterson, M., McEvoy, F. and Stephenson, M., 2005. Sustainable minerals operations in the developing world: introduction. Geological Society, London, Special Publications, 250(1): 1-4.

[9] Asklund, R. and Eldvall, B., 2005. Contamination of water resources in Tarkwa mining area of Ghana. Resource, 27: 61-75.

[10] Donkor, A., Bonzongo, J., Nartey, V. and Adotey, D., 2006. Mercury in different environmental compartments of the Pra River Basin, Ghana. Science of the Total Environment, 368(1): 164-176.

[11] Dumett, R. E., 1998. El Dorado in West Africa: the goldmining frontier, African labor, and colonial capitalism in the Gold Coast, 1875-1900. James Currey Publishers.

[12] Mahmood, A. and Malik, R. N., 2014. Human health risk assessment of heavy metals via consumption of contaminated vegetables collected from different irrigation sources in Lahore, Pakistan. Arabian Journal of Chemistry, 7(1): 91-99.

[13] Ghana Statistical Service, 2012. 2010 Population and Housing Census, summary report of final results. Accra-Ghana: Sakoa Press Ltd. Retrieved September 11, 2012, from www.statsghana.gov.gh

[14] Ansah-Asare, O. and Asante, K., 2008. The water quality of Birim river in South-East Ghana. West African Journal of Applied Ecology, 1(1): 23-34.

[15] Pohl, D., 1998. A decade of change-mineral exploration in West Africa. Journal-South African Institute of Mining And Metallurgy, 98: 311-316.

[16] Rae, J., 2009. Technical Report On the Kibi Goldfields Mine Kwabeng Gold Project.
[17] Bartram, J. and Ballance, R., 1996. Water quality monitoring: a practical guide to the design and implementation of freshwater quality studies and monitoring programmes. CRC Press.

[18] Sullivan, A. B. and Drever, J. I., 2001. Geochemistry of suspended particles in a mine-affected mountain stream. Applied Geochemistry, 16(15): 1663-1676.

[19] Gill, R., 2014. Modern Analytical Geochemistry: an introduction to quantitative chemical analysis techniques for Earth, environmental and materials scientists. Routledge.

[20] Shimamura, T., 1997. Inductively coupled plasma mass spectrometry (ICP-MS).

[21] Jarvis, K. E., 1997. Inductively coupled plasma-mass spectrometry. Modern analytical geochemistry. Ed. by R. Gill. Longman, London.

[22] Survey, G. G., Kerbyson, J. and Schandorf, J., 1966. Chemical Analyses of Ghana Rocks, Ores, and Minerals, 1948-1963. Ministry of Information and Broadcasting.

[23] Joint, F. and Organization, W. H., 2005. Vitamin and mineral requirements in human nutrition.

[24] El-Serag, H. B. and Rudolph, K. L., 2007. Hepatocellular carcinoma: epidemiology and molecular carcinogenesis. Gastroenterology, 132(7): 2557-2576.

[25] Zhao, L., Wang, L., Yang, D. and Zhu, N., 2007. Bioleaching of spent $\mathrm{Ni}-\mathrm{Cd}$ batteries and phylogenetic analysis of an acidophilic strain in acidified sludge. Frontiers of Environmental Science \& Engineering in China, 1(4): 459465 .

[26] Addo, M. et al., 2011. Water quality and level of some heavy metals in water and sediments of Kpeshie Lagoon, La-Accra, Ghana.

[27] Miller, J. and Lechler, P., 2003. Importance of temporal and spatial scale in the analysis of mercury transport and fate: an example from the Carson River system, Nevada. Environmental Geology, 43(3): 315-325.

[28] Rodricks, J. V., 1992. Calculated Risks: Understanding the toxicity and human health risks of chemicals in our environment. Cambridge University Press.

[29] Langmuir, D., Hall, P. and Drever, J., 1997. Environmental Geochemistry. Prentice Hall, New Jersey.

[30] Banks, D., Reimann, C., Røyset, O., Skarphagen, H. and Sæther, O. M., 1995. Natural concentrations of major and trace elements in some Norwegian bedrock groundwaters. Applied Geochemistry, 10(1): 1-16.

[31] Lahermo, P., Mannio, J. and Tarvainen, T., 1995. The hydrogeochemical comparison of streams and lakes in Finland. Applied geochemistry, 10(1): 45-64. 


\section{Bibliography}

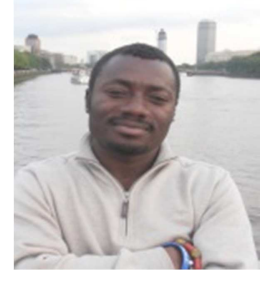

Bright Oppong Afum is a Lecturer in the Mining Engineering Dept. of the University of Mines and Technology (UMaT). He holds degrees in BSc Mining Engineering from the Kwame Nkrumah University of Science and Technology (KNUST), and MSc Environmental Monitoring and Analysis from the Aberystwyth University, UK. He has worked in an explosives and underground mining companies before joining UMaT. He is a member of the Society for Mining, Metallurgy and Exploration (MSME), the Australasian Institute of Mining and Metallurgy (MAusIMM) and the Ghana Institution of Engineers (GMGhIE). He is currently a $\mathrm{PhD}$ researcher at UMaT.

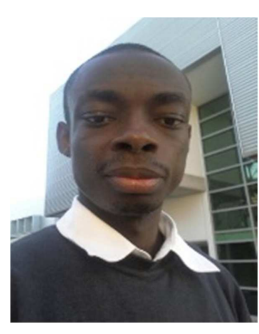

Clement Owusu completed his $\mathrm{PhD}$ in Minerals and Materials Engineering at the Ian Wark Research Institute, University of South Australia. He received a BSc. degree in Minerals Engineering from the University of Mines and Technology (UMaT), Tarkwa, Ghana. He is currently a Lecturer at the Minerals Engineering Department of UMaT. Clements's areas of interest include Fine Particle Flotation of Sulphide Minerals, Surface Chemistry of Minerals. Physical and Chemical Processes in Extractive Metallurgy, Mass Balance, and Fundamental and Applied Studies. He is a member of the Institution of Chemical Engineers (MIChemE). 